\title{
PENGARUH HARGA DAN KUALITAS PELAYANAN \\ TERHADAP KEPUTUSAN PEMBELIAN KONSUMEN \\ (Studi Kasus Pada CV. XP Computer, Boyolali) \\ Fitriana Dewi ${ }^{1}$, Listyowati Puji $\mathbf{R}^{2}$, Unna Ria Safitri ${ }^{3}$ \\ dfitriana909@gmail.com \\ Universitas Boyolali
}

\begin{abstract}
ABSTRAK
Berdasarkan hasil penelitian diketahui bahwa harga secara parsial tidak berpengaruh pada keputusan pembelian hal ini dibuktikan dengan nilai thitung $<$ ttabel yakni $-0,243<1,984$. Sedangkan untuk kualitas pelayanan diketahui bahwa secara parsial berpengaruh pada keputusan pembelian. Hal ini dibuktikan pada butir kualitas pelayanan mengenai keandalan dan jaminan yang nilai thitung > tabel yakni 3,986>1,984 dan 2,011 > 1,984. Hasil uji determinasi terdapat pengaruh antara harga dan kualitas pelayanan terhadap keputusan pembelian sebesar $38 \%$ sedangkan $62 \%$ dipengaruhi oleh faktor lain yang tidak diteliti pada penelitian ini.
\end{abstract}

\section{Kata kunci : Harga, Kualitas Pelayanan, Keputusan Pembelian}

\begin{abstract}
Based on the results of the study note that the price of a partial no effect on purchasing decisions this is evidenced by the value of $t$ count $<t$ table it's about $-0.2243<1.984$. As for the quality of service is known that the partial effect on purchasing decisions. This is evidenced in the grain of service quality regarding the reliability and assurance that the value of tcount $>$ table 3.986> 1.984 and 2.011> 1.984. Determination test result there is influence between price and quality of service to decision of purchase equal to $38 \%$ whereas $62 \%$ influenced by other factor not examined in this research.
\end{abstract}

Keywords: Price, Service Quality, Purchase Decision 


\section{PENDAhUluan}

\section{Latar Belakang Penelitian}

Pada zaman sekarang ini kebutuhan hidup semakin beraneka ragam. Perkembangan Ilmu Pengetahuan dan Teknologi (IPTEK) yang semakin maju membuat masyarakat tidak bisa mengelak dan mau tidak mau harus mengikuti perkembangannya. Banyak kegiatan yang perlu dikerjakan menggunakan alat yang benama komputer atau laptop. Hampir semua orang saat ini sudah bisa melakukan pekerjaan dan mengoperasikan laptop atau. Dalam melakukan pekerjaan, pasti akan terjadi laptop atau netbook mengalami masalah. Sesuatu yang berhubungan dengan teknologi membuat kita mau tidak mau jika mengalami kerusakan harus segera diselesaikan agar tidak mengganggu kegiatan kita dalam menyelesaikan pekerjaan. Pemenuhan kebutuhan untuk bisa melakukan pekerjaan dengan baik dan benar, masyarakat membutuhkan adanya suatu pelayanan tentang teknologi dan komunikasi yang berupa suatu toko atau bahkan pelayanan jasa.

Banyak sekali faktor-faktor yang mempengaruhi terhadap keputusan pembelian konsumen, yang secara teoritis keputusan pembelian yang dilakukan oleh konsumen terhadap barang yang ditawarkan sangat dipengaruhi oleh harga, produk, pelayanan, lokasi perusahaan atau toko (Kotler 1996:165). Tjiptono (2008 : 151-152 ) harga adalah jumlah uang yang dibebankan atau dikenakan atas sebuah produk atau jasa. Dengan kata lain harga merupakan sebuah nilai yang harus ditukarkan dengan produk yang dikehendaki konsumen. Harga yang terjangkau dan bersaing menjadi faktor utama keputusan pembelian konsumen. Toko yang menjual berbagai macam jenis barang dengan harga yang terjangkau dan menyediakan berbagai jenis atau Merek produk yang beraneka ragam, akan membuat konsumen lebih leluasa dalam memilih produk.

Menurut Tjiptono, Kualitas pelayanan merupakan suatu kondisi dinamis yang berpengaruh dengan produk, jasa, manusia, proses dan lingkungan yang memenuhi atau melebihi harapan. Artinya adalah upaya pemenuhan kebutuhan dan keinginan konsumen, serta ketepatan penyampaian dalam mengimbangi harapan konsumen.

Sehingga kemungkinan harga bisa berpengaruh pada keputusan pembelian konsumen diimbangi dengan jasa yang diberikan sesuai dengan apa yang diharapkan konsumen maka kualitas pelayanan yang diberikan memuaskan.

\section{Rumusan Masalah}

Rumusan masalah dalam penelitian ini adalah sebagai berikut : Apakah ada pengaruh harga dan kualitas pelayanan terhadap keputusan pembelian konsumen pada CV. XP Computer dan seberapa besarnya pengaruh harga dan kualitas pelayanan terhadap keputusan pembelian konsumen pada CV. XP Computer, Boyolali.

\section{Tujuan Penelitian}

Tujuan dari penelitian ini adalah untuk mengetahui apakah ada pengaruh harga dan kualitas pelayanan pelayanan terhadap keputusan pembelian konsumen pada CV. XP Computer, serta mengetahui besarnya pengaruh harga dan kualitas pelayanan terhadap keputusan pembelian konsumen pada CV. XP Computer, Boyolali. 


\section{Tinjauan Pustaka Pengertian harga}

Menurut Tjiptono (1997:151) harga merupakan sesuatu yang diserahkan dalam pertukaran untuk mendapatkan suatu barang atau jasa. Kotler dan Amstrong (2008: 345) mengatakan bahwa harga adalah jumlah uang yang ditagihkan atas suatu produk atau jasa. Indikator - indikator harga menurut Kotler dan Armstrong (2008:346) diantaranya:

1. Keterjangkauan harga

2. Kesesuaian harga dengan kualitas produk atau jasa

3. Daya saing harga

4. Kesesuaian harga dengan manfaat yang dirasakan

\section{Kualitas Pelayanan}

Menurut Tjiptono (2005:51) kualitas pelayanan adalah suatu penyajian produk atau jasa sesuai ukuran yang berlaku di tempat produk tersebut diadakan dan penyampaiannya setidaknya sama dengan yang diinginkan dan diharapkan oleh konsumen. Kualitas pelayanan menurut Kotler dan Keller (2008 : 56) merangkup 5 dimensi pokok yang terdiri dari :

1. Daya tanggap (responsiveness), yang menunjukkan kemauan

\section{METODOLOGI PENELITIAN}

Metode yang digunakan yaitu dengan menggunakan teknik analisis deskriptif dan studi kasus. Sumber data yang digunakan adalah data primer dan data sekunder. Sampel pada penelitian ini sebanyak 100 orang yaitu semua konsumen yang pernah atau sedang melakukan pembelian di CV. XP Computer, Boyolali. Teknik pengumpulan data yaitu dengan kuesioner. Variabel yang digunakan dalam penelitian ini yaitu untuk membantu pelanggan dan memberikan jasa dengan cepat atau tanggap.

2. Jaminan (assurance)

menunjukan sejauh mana pengetahuan dan kesopanan karyawan serta kemampuan menciptakan image atau persepsi yang baik bagi perusahaan, dengan menumbuhkan kepercayaan dan keyakinan dibenak konsumen terhadap perusahaan.

3. Empati (empathy), sebagai syarat untuk peduli dan memberikan perhatian secara pribadi bagi pelanggan.

4. Bukti fisik (tangible) berupa penampilan fasilitas fisik, peralatan, personel dan media komunikasi.

Beberapa dari sekian faktor yang mempengaruhi konsumen dalam melakukan pembelian suatu produk atau jasa, biasanya konsumen selalu mempertimbangkan kualitas, harga dan produk sudah yang sudah dikenal oleh masyarakat. Sebelum konsumen memutuskan untuk membeli, biasanya konsumen melalui beberapa tahap terlebih dahulu yaitu pengenalan masalah, pencarian informasi, evaluasi alternatif, keputusan pembelian (membeli atau tidak) dan perilaku pasca pembelian.

harga (X1), Kualitas Pelayanan (X2) dan Keputusan Pembelian konsumen (Y).

Pengujian instrumen data dilakukan dengan uji validitas dan uji reliabilitas, sedangkan analisis data yang digunakan adalah, koefisien determinasi, uji asumsi klasik (uji normalitas menggunakan analisis durbin watson, uji autokorelasi, uji multikolinieritas, serta uji heteroskedastisitas). 


\section{HASIL PENELITIAN}

\section{Analisis Validitas Harga terhadap Keputusan Pembelian Konsumen} Pengukuran pengaruh harga dilakukan dengan memberikan 5 pernyataan kepada responden. Hasil penelitian berupa rekapitulasi jumlah skor jawaban responden terhadap harga, diperoleh hasil $r$ hitung lebih dari $r$ tabel sehingga semua pernyataan mengenai harga valid.

\section{Analisis Validitas Kualitas Pelayanan terhadap Keputusan Pembelian Konsumen}

Pengukuran kualitas pelayanan terhadap keputusan pembelian dilakukan dengan memberikan 22 pernyataan kepada responden. Hasil penelitian berupa rekapitulasi jumlah skor Uji Asumsi Klasik

a. Uji Normalitas Gambar Uji Normalitas

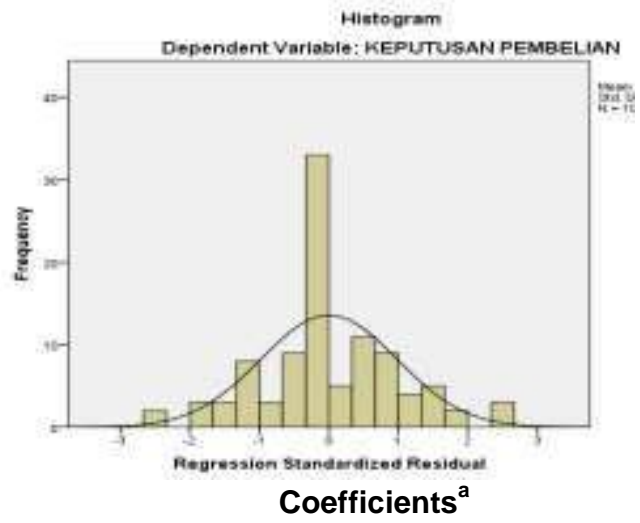

jawaban responden terhadap kualitas pelayanan, diperoleh hasil $r_{\text {hitung }}$ lebih dari $r_{\text {tabel }}$ sehingga semua pernyataan mengenai kualitas pelayanan valid.

\section{Analisis Validitas terhadap Keputusan Pembelian Konsumen}

Pengukuran keputusan pembelian dilakukan dengan memberikan 5 pernyataan kepada responden. Hasil penelitian berupa rekapitulasi jumlah skor jawaban responden terhadap keputusan pembelian, diperoleh hasil $r$ hitung lebih dari $r$ tabel sehingga semua pernyataan terhadap keputusan pembelian valid.

b. Uji multikolinearitas

Berdasarkan gambar disamping dapat diketahui bahwa nilai Z-Kurtosis pada hasil uji variabel harga dan kualitas pelayanan masing-masing memiliki nilai sebesar 1,48 dan 0,16 maka nilainya diantara $-1,96$ dan $+1,96$, berarti data memiliki keruncingan mesokurtik (bagian tengah distribusi data memiliki puncak diantara leptokurtic dan platykurtic).

Sehingga bisa dikatakan variabel dalam penelitian ini mempunyai distribusi data yang normal atau layak dipakai karena asumsi normalitas (Ghozali 2011 : 163).

\begin{tabular}{|c|c|c|c|c|c|c|c|}
\hline \multirow{2}{*}{ Model } & \multicolumn{2}{|c|}{$\begin{array}{l}\text { Unstandardize } \\
\text { d Coefficients }\end{array}$} & $\begin{array}{l}\text { Standardi } \\
\text { zed } \\
\text { Coefficie } \\
\text { nts }\end{array}$ & \multirow{2}{*}{$\mathrm{T}$} & \multirow{2}{*}{ Sig. } & \multicolumn{2}{|c|}{$\begin{array}{l}\text { Collinearity } \\
\text { Statistics }\end{array}$} \\
\hline & B & $\begin{array}{l}\text { Std. } \\
\text { Error }\end{array}$ & Beta & & & $\begin{array}{c}\text { Toleran } \\
\text { ce }\end{array}$ & VIF \\
\hline (Constant) & $\begin{array}{r}5,49 \\
6\end{array}$ & 2,002 & & $\begin{array}{r}2,74 \\
5\end{array}$ & $\begin{array}{r}, 00 \\
7\end{array}$ & & \\
\hline $\begin{array}{l}\text { KEANDALA } \\
\mathrm{N}\end{array}$ & ,416 & , 104 & ,416 & $\begin{array}{r}3,98 \\
6\end{array}$ & $\begin{array}{r}, 00 \\
0\end{array}$ & ,576 & $\begin{array}{r}1,73 \\
5\end{array}$ \\
\hline JAMINAN & ,252 & ,125 & ,199 & $\begin{array}{r}2,01 \\
1\end{array}$ & $\begin{array}{r}, 04 \\
7\end{array}$ & ,642 & $\begin{array}{r}1,55 \\
7\end{array}$ \\
\hline $\begin{array}{l}\text { BERWUJU } \\
\text { D }\end{array}$ & ,260 & ,374 & ,204 & ,695 & $\begin{array}{r}48 \\
9\end{array}$ & $\begin{array}{r}073 \\
1\end{array}$ & $\begin{array}{r}13,7 \\
39\end{array}$ \\
\hline $\begin{array}{l}\text { PENGARU } \\
\text { H HARGA }\end{array}$ &,- 075 & ,311 &,- 072 &,- 243 & $\begin{array}{r}, 80 \\
8\end{array}$ & ,071 & $\begin{array}{r}14,1 \\
25\end{array}$ \\
\hline
\end{tabular}


Berdasarkan tabel disamping diperoleh hasil bahwa nilai tolerance variabel keandalan $0,576>0,1$ nilai VIF $1,735<10$ dan tolerance variabel jaminan $0,642>0,1$ nilai VIF $1,557<10$

maka dapat disimpulkan antara variabel bebas kualitas pelayanan butir keandalan dan jaminan tidak terjadi multikolinearitas. Namun pada variabel bebas pengaruh harga dan kualitas pelayanan butir berwujud hasil uji tolerance

$<0,1$ dan VIF $>10$ sehingga terjadi multikolinearitas. 
c.Uji Heterokedastisitas

Dalam uji heterokedastisitas ini mempunyai tujuan apakah dalam model regresi terjadi ketidaksamaan varian dari residual suatu pengamatan ke pengamatan lain.

Hasil Uji Normalitas Data menggunakan P-Plot

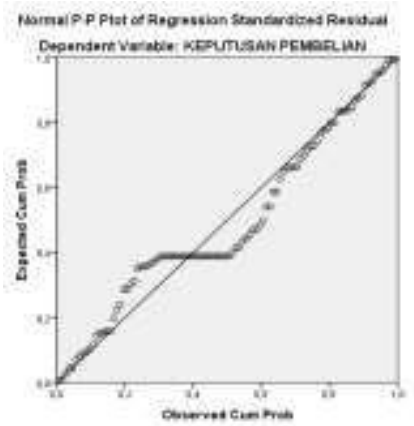

Pada grafik normal plot terlihat titik-titik menyebar di sekitar garis diagonal, penyebarannya mengikuti arah garis diagonal menunjukkan pola distribusi normal dan model regresi layak dipakai karena asumsi normalitas (Ghozali 2011 : 163). d.Uji Autokolerasi

Tabel hasil uji autokolerasi dengan Durbin Watson

\begin{tabular}{|l|r|r|r|r|r|}
\hline $\begin{array}{l}\text { Mode } \\
\mathrm{I}\end{array}$ & $\mathrm{R}$ & $\begin{array}{c}\mathrm{R} \\
\text { Squar } \\
\mathrm{e}\end{array}$ & $\begin{array}{c}\text { Adjust } \\
\text { ed R } \\
\text { Squar } \\
\mathrm{e}\end{array}$ & $\begin{array}{c}\text { Std. } \\
\text { Error of } \\
\text { the } \\
\text { Estimate }\end{array}$ & $\begin{array}{c}\text { Durbin } \\
- \\
\text { Watso } \\
\mathrm{n}\end{array}$ \\
\hline 1 &, $636^{\mathrm{a}}$ &, 405 &, 380 & 1,786 & 1,438 \\
\hline
\end{tabular}

a. Predictors: (Constant), PENGARUH HARGA, JAMINAN, KEANDALAN, BERWUJUD

b. Dependent Variable: KEPUTUSAN PEMBELIAN
Dari hasil analisis, dapat diketahui bahwa Durbin Watson sebesar 1,438. Pengujian autokolerasi dengan melihat tabel Durbin Watson antara jumlah predictors (k) yang berjumlah 4 dan jumlah sampel (n) 100, tingkat signifikan $0,05)$ diperoleh nilai $\mathrm{dL} 1,592$ dan $\mathrm{dU}$ 1,758 dapat disimpulkan bahwa nilai $d$ diantara batas bawah dL dan batas atas dU artinya penelitian ini tidak terjadi autokolerasi.

\section{Coefficients $^{a}$}

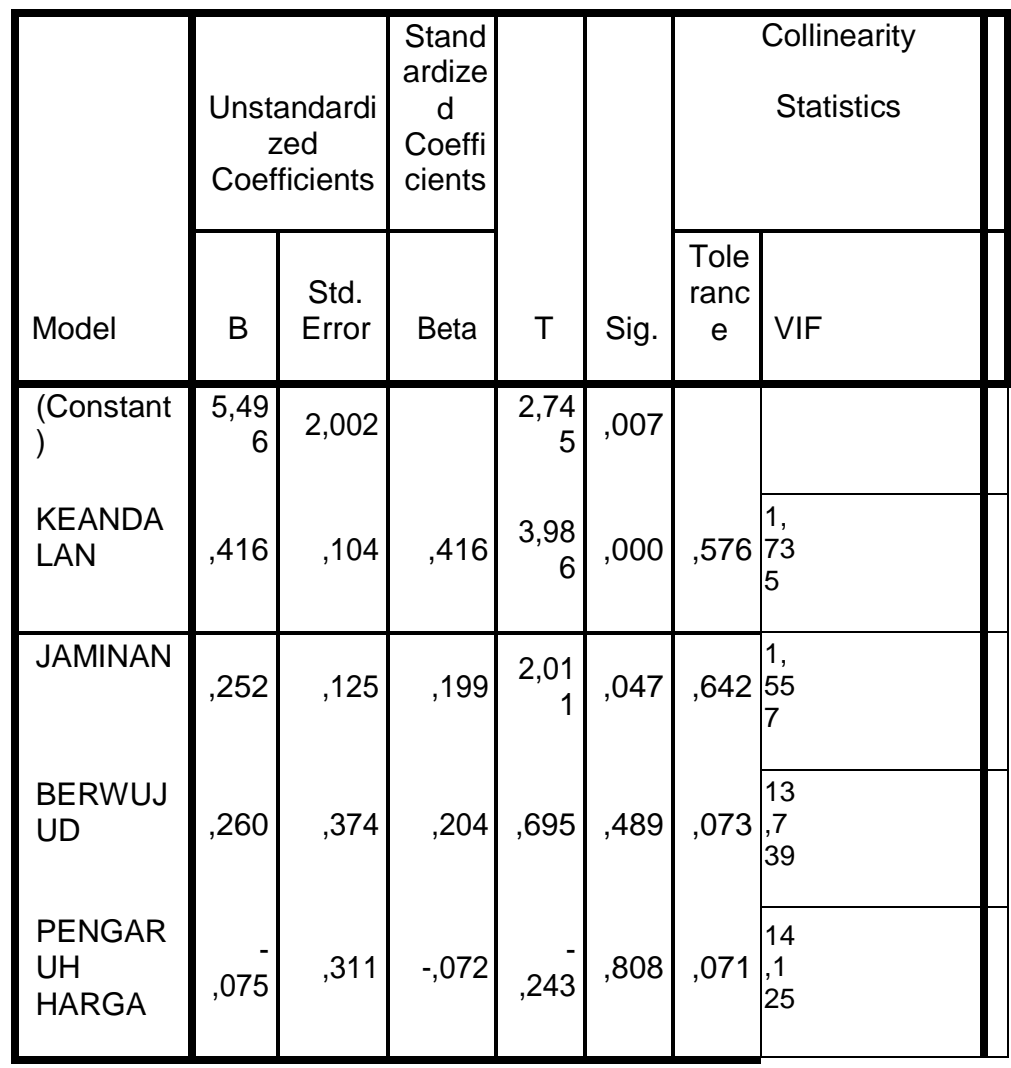

a. Dependent Variable: KEPUTUSAN PEMBELIAN

\section{Uji Hipotesis}

Hasil Uji t (parsial)

1) Menguji signifikasi variabel pengaruh harga $\left(\mathrm{X}_{1}\right)$ terhadap keputusan pembelian (Y) adalah thitung < tabel yakni -0,243< 1,984. Maka $\mathrm{H}_{0}$ diterima dan $\mathrm{H}_{1}$ ditolak, sehingga dapat disimpulkan bahwa koefisien pengaruh harga secara parsial 
tidak berpengaruh signifikan terhadap keputusan pembelian. Hasil penelitian membuktikan bahwa harga tidak menjadi faktor utama dalam keputusan pembelian, selanjutnya mungkin ada faktor lain yang lebih diperhatikan oleh pelanggan dalam menentukan sebuah produk atau nilai tertentu sebelum melakukan keputusan pembelian.

2) Menguji signifikasi variabel kualitas pelayanan (X) dengan pernyataan keandalan terhadap keputusan pembelian (Y) adalah thitung $>$ tabel yakni 3,986>1,984. Maka $\mathrm{H}_{0}$ ditolak dan $\mathrm{H}_{1}$ diterima, sehingga dapat disimpulkan bahwa koefisien kualitas pelayanan dengan item keandalan secara parsial berpengaruh signifikan terhadap keputusan pembelian.

3) Menguji signifikasi variabel kualitas pelayanan $\left(\mathrm{X}_{1}\right)$ dengan pernyataan jaminan terhadap keputusan pembelian (Y) adalah thitung $>$ tabel yakni 2,011 > 1,984. Maka $\mathrm{H}_{0}$ ditolak dan $\mathrm{H}_{1}$ diterima, sehingga dapat disimpulkan bahwa koefisien kualitas pelayanan variabel jaminan secara parsial berpengaruh, namun tidak signifikan terhadap keputusan pembelian konsumen pada $\mathrm{CV}$. XP Comp Boyolali.

4) Menguji signifikasi variabel kualitas pelayanan $\left(\mathrm{X}_{1}\right)$ dengan pernyataan berwujud terhadap keputusan pembelian (Y) adalah thitung $<$ tabel yakni $0,695<1,984$. Maka $\mathrm{H}_{0}$ diterima dan $\mathrm{H}_{1}$ ditolak, sehingga dapat disimpulkan bahwa koefisien kualitas pelayanan dengan item berwujud secara parsial tidak berpengaruh signifikan terhadap keputusan pembelian.

\section{Uji Simultan ( Uji F)}

Hasil diketahui bahwa Fhitung $>$ Ftabel (2 :100- 2) yakni 16,173 > 3,09 sehingga dapat disimpulkan bahwa harga dan kualitas

ANOVA $^{\mathrm{a}}$

\begin{tabular}{|l|r|r|r|r|r|}
\hline Model & $\begin{array}{r}\text { Sum } \\
\text { of } \\
\text { Squar } \\
\text { es }\end{array}$ & Df & $\begin{array}{c}\text { Mean } \\
\text { Square }\end{array}$ & F & Sig. \\
\hline Regression & $\begin{array}{r}206,2 \\
66\end{array}$ & 4 & 51,566 & 16,173 &, $000^{\mathrm{b}}$ \\
Residual & $\begin{array}{r}302,8 \\
94\end{array}$ & 95 & 3,188 & & \\
Total & $\begin{array}{r}509,1 \\
60\end{array}$ & 99 & & & \\
\hline
\end{tabular}

a. Dependent Variable: KEPUTUSAN PEMBELIAN

b. Predictors: (Constant), PENGARUH HARGA, JAMINAN, KEANDALAN, BERWUJUD

pelayanan secara simultan berpengaruh terhadap keputusan pembelian. Begitu pula hasil uji dengan menggunakan uji nilai signifikan. Hasil yang diperoleh hasil uji signifikasi sebesar 0,00 sedangkan nilai signifikasi pada keputusan yang digunakan $<0,05$ maka signifikasi $0,00<0,05$ memberikan hasil keputusan bahwa harga dan kualitas pelayanan secara simultan berpengaruh terhadap keputusan pembelian.

Uji Koefisien Determinasi

\begin{tabular}{|l|r|r|r|r|r|}
\hline $\begin{array}{l}\text { Mod } \\
\text { el }\end{array}$ & $\mathrm{R}$ & $\begin{array}{r}\mathrm{R} \\
\mathrm{R} \\
\mathrm{re}\end{array}$ & $\begin{array}{c}\text { Adjust } \\
\text { ed R } \\
\text { Squar } \\
\mathrm{e}\end{array}$ & $\begin{array}{c}\text { Std. } \\
\text { Error of } \\
\text { the } \\
\text { Estimate }\end{array}$ & $\begin{array}{c}\text { Durbin- } \\
\text { Watson }\end{array}$ \\
\hline 1 & $\begin{array}{r}636 \\
\mathrm{a}\end{array}$ &, 405 &, 380 & 1,786 & 1,438 \\
\hline
\end{tabular}

a. Predictors: (Constant), PENGARUH HARGA, JAMINAN, KEANDALAN, BERWUJUD

b. Dependent Variable: KEPUTUSAN PEMBELIAN 
Berdasarkan hasil uji diatas dapat besarnya Adjusted R Square adalah secara bersama-sama mampu menjelaskan variabel keputusan pembelian sebesar $38 \%$ sedangkan $62 \%$ dijelaskan oleh variabel sebab-sebab
0,380. Hal ini menujukkan bahwa variabel harga dan kualitas pelayanan lainnya diluar variabel yang diteliti seperti faktor lokasi, kualitas produk, citra perusahaan, promosi, WORD OF $M O U T H \quad$ dan lain

\section{PEMBAHASAN}

1. Pengaruh harga terhadap kualitas pelayanan

Hasil uji hipotesis yang dilakukan dapat disimpulkan bahwa harga tidak berpengaruh terhadap keputusan pembelian konsumen pada CV. XP Computer. Hal ini dibuktikan dengan hasil uji $\mathrm{t}$ hitung $-0,243$ lebih kecil dari $\mathrm{t}$ tabel 1,984 sehingga $\mathrm{H}_{0}$ diterima dan $\mathrm{H}_{1}$ ditolak. Ukuran harga tidak menjadi alasan utama dalam menentukan pilihan sebuah produk. Banyak konsumen yang lebih mengutamakan kualitas daripada harga sehingga mereka lebih menghargai suatu nilai (harga) jika barang yang ditawarkan mempunyai kualitas yang sesuai dengan apa yang telah mereka bayarkan.

Dari hasil penelitian menujukkan mayoritas responden yang melakukan pembelian adalah responden yang memiliki pekerjaan pegawai swasta dan berusia 20-29 tahun yang berfikir bahwa harga tidak menjadi alasan dalam penentuan pembelian dan lebih mengutamakan kualitas yang diberikan karena rentan umur tersebut dalam pemakaian suatu produk masih akan berlangsung lama, maka akan mencari atau membeli suatu produk yang daya tahannya atau keawetannya atau bisa karena masa garansi yang cukup lama walaupun harga sedikit lebih tinggi.
2. Pengaruh kualitas pelayanan terjadap keputusan pembelian

Hasil pengujian hipotesis yang dilakukan menunjukkan bahwa kualitas pelayanan berpengaruh terhadap keputusan pembelian dengan butir pernyataan mengenai keandalan dan jaminan yakni hasil thitung > ttabel untuk keandalan 3,986 > 1,984 dan untuk jaminan 2,011>1,984 sehingga $\mathrm{H}_{\mathrm{o}}$ ditolak dan $\mathrm{H}_{1}$ diterima. Hal ini membuktikan bahwa pelayanan dalam suatu instansi mempengaruhi dalam keputusan pembelian. Pelayanan yang baik akan membuat para pelanggan merasa nyaman dan diperhatikan karena rasa kepuasaan akan mempengaruhi tentang keputusan pembelian dan pasti akan berpengaruh pada kelangsungan hidup suatu usaha. Dengan pelayanan yang bisa dihandalkan dan jaminan mutu yang diberikan bagus membuat konsumen dapat percaya bahwa di CV. XP Computer bisa memberikan apa yang mereka inginkan. Dari pelayanan mengenai penjualan produk, service, hingga mencarikan suatu produk tertentu dengan memesan terlebih dahulu dan jika sudah ada barangnya, pelanggan akan diinformasikan melalui media telefon serta adanya jaminan atau garansi yang diberikan membuat konsumen lebih nyaman dan tidak khawatir jika produk tersebut mengalami kerusakan. 


\section{KESIMPULAN DAN SARAN \\ Kesimpulan}

1. Tidak ada pengaruh yang signifikan antara variabel harga terhadap keputusan pembelian. Hal ini dibuktikan dengan melakukan uji parsial $(\mathrm{t})$ dimana hasil thitung $<$ ttabel yakni $-0,243<1,984$.

2. Ada pengaruh yang signifikan antara variabel kualitas pelayanan dengan butir pernyataan mengenai keandalan terhadap keputusan pembelian. Hal ini dibuktikan dengan melakukan uji parisal $(\mathrm{t})$ dimana hasil thitung $>\mathrm{t}$ tabel yakni 3,986 > 1,984 sehingga terdapat pengaruh yang signifikan antara variabel kualitas pelayanan dengan butir keandalan terhadap keputusan pembelian pada CV. XP Computer.

3. Ada pengaruh antara variabel kualitas pelayanan dengan butir pernyataan mengenai jaminan terhadap keputusan pembelian. Hal ini dibuktikan dengan melakukan uji parsial (t) dimana hasil thitung > tabel yakni 2,011> 1,984 jadi kesimpulannya terdapat pengaruh namun tidak signifikan antara variabel kualitas pelayanan dengan butir jaminan terhadap keputusan pembelian pada CV. XP Computer.

4. Tidak ada pengaruh yang signifikan antara variabel kualitas pelayanan mengenai berwujud terhadap keputusan pembelian. Hal ini dibuktikan dengan melakukan uji $\mathrm{t}$ dimana hasil menunjukan thitung < tabel yakni 0,695 < 1,984 jadi tidak ada pengaruh signifikan antara kualitas pelayanan dengan variabel berwujud terhadap keputusan pembelian pada CV. XP Computer.

5. Berdasarkan uji $\mathrm{F}$ diketahui bahwa variabel pengaruh harga dan kualitas pelayanan secara bersama-sama mempengaruhi keputusan pembelian. Uji $\mathrm{F}$ dibandingkan dengan $\mathrm{F}$ tabel ${ }_{(\mathrm{k}: \mathrm{n} \text { - }}$ k). $\mathrm{F}$ tabel diketahui dari $\mathrm{k}=\mathrm{jumlah}$ variael bebas dan $n=$ jumlah responden. Maka dari perhitungan diatas diperoleh hasil Fhitung > Ftabel 16,173 > 3,09 dan dengan nilai signifikan pada hasil uji adalah $0,00<0,05$ maka variabel harga dan kualitas pelayanan secara simultan berpengaruh terhadap keputusan pembelian.

6. Berdasarkan uji determinasi yang sudah dilakukan, diketahui bahwa nilai $\mathrm{R}$ square adalah 0,380 maka dapat diketahui bahwa variabel harga dan kualitas pelayanan secara bersamaan mampu menjelaskan variabel keputusan pembelian sebesar $38 \%$.

\section{Saran}

1. CV. XP Computer saat penelitian ini belum perlu menaikkan atau menurunkan harga karena secara signifikan harga tidak berpengaruh pada keputusan pembelian konsumen. Bagi konsumen harga tidak menjadi masalah karena yang mereka utamakan yakni kualitas dari produk itu sendiri, serta adanya jaminan yang membuat konsumen mau mengeluarkan harga yang sedikit lebih tinggi dengan kualitas dan jaminan mutu yang bagus.

2. CV. XP Computer perlu mempertahankan kualitas pelayanan yang selama ini telah dilakukan kepada konsumen dan meningkatkannya karena kualitas pelayanan yang memuaskan akan mempengaruhi konsumen untuk melakukan keputusan pembelian kembali pada CV. XP Computer. Faktor keramahan karyawan menjadi faktor yang sangat penting atau berpengaruh karena sikap karyawan yang ramah dan mampu menyelesaikan pelayanan dari awal hingga akhir akan membuat konsumen merasa senang dan nyaman dalam menerima pelayanan yang diberikan oleh CV. XP Computer. 


\section{DAFTAR PUSTAKA}

Arikunto, Suharsimi. 1997. Prosedur Penelitian Suatu Pendekatan Praktek. Jakarta : Rineka Cipta.

Assauri, Sofjan. 1996. Manajemen Pemasaran Dasar Konsep dan Strategi. Jakarta : Rajawali Press.

Atmaja, Desy Purwanti dan Martius Febrian Adiwinata. 2009. Pengaruh Produk, Harga, Lokasi dan Kualitas Layanan Terhadap Keputusan Pembelian Di Kopitiam Oey Surabaya, Jurnal Manajemen Perhotelan, Surabaya. Surabaya

Basu Swastha, Hani Handoko. 2011. Manajemen Pemasaran Analisis Perilaku Konsumen. Yogyakarta: BPFE.

Basu, Swastha. 2000. Pengantar Bisnis Modern dan Pengantar Ekonomi Perusahaan Modern. Jakarta: Liberty.

Bungin, Burhan. 2011. Metodologi Penelitian Kuantitatif. Jakarta: Kencana.

Djaslim, Saladin. 1996. Unsur-Unsur Inti Pemasaran dan Manajemen Pemasaran. Bandung: Mandar Maju.

Drs. Danang Sunyoto, S.H, S.E, M.M. 2014. Konsep Riset Pemasaran dan Perilaku Konsumen. Yogyakarta.

Ghozali, Imam. 2011. Aplikasi Analisis Multivariate Dengan Program SPSS. Semarang : Universitas Diponegoro.
Ghozali dan Casstelan. 2002. Statistik non Parametik "Teori dan Aplikasi dengan program spss”. Semarang: Badan Penerbit Universitas Diponegoro.

Gitosudarmo, I. (2000). Manajemen Pemasaran. Edisi pertama cetakan keenam. Yogyakarta. BPFE

Kotler , Gerry Amstrong. 2008. Prinsipprinsip Pemasaran. Jilid 1 dan 2. Edisi 12. Jakarta: Erlangga.

Kotler, Kevin Keller. 2009. Manajemen Pemasaran. Jilid 2. Edisi ke 13. Terjemahan Bob Sabran MM. Jakarta: Erlangga.

Kotler P. dan K. L. Keller. 2008. Manajemen Pemasaran. Edisi 12. Jilid 1. Penerbit PT. Indeks Gramedia. Jakarta

Kotler, Philip. 2000. Manajemen Pemasaran. Edisi Mileinium. Jakarta: PT. Indeks Kelompok Gramedia.

Nova Dhita Kurniasari, Suryono Budi Santoso, 2013. Analisis Pengaruh Harga, Kualitas Produk dan Kualitas PelayananTerhadap Keputusan Pembelian pada Waroeng Steak and Shake Semarang. Jurnal Manajemen. Universitas Diponegoro. Semarang

Prof. Dr. Ir. Sugiarto M.Sc. 2008. Metodelogi Penelitian. Jakarta.

Tjiptono, Fandy. 2008. Strategi Pemasaran. Edisi 3. Yogyakarta: ANDI.

Tjiptono, Fandy. 2009. Strategi Pemasaran. Edisi kedua. Cetakan Ketujuh. Yogyakarta: ANDI. 
EKOBIS : JURNAL ILMU MANAJEMEN DAN AKUNTANSI

ISSN : 2502-3055

Vol. 8 No. 1, Juni 2020

e-ISSN : 2622-17

Zimmerer, T.W dan Scarborough, N. M. 2009."Essentials of Entreprenuership and Small Business Management", Prentice Hall. U.S.A 